\title{
Pornography, 'The False Heaven of Modern Societies' and' The Implication for the Young Generation
}

\author{
I Ketut Suda \\ suda.unhidps@yahoo.co.id \\ Postgraduate Program, Universitas Hindu Indonesia \\ Ida Bagus Rai \\ Dwijendra University Denpasar \\ Ib.rai.undwi@gmail.com \\ I Made Sila \\ Dwijendra University Denpasar \\ madesila@undwi.ac.id
}

\begin{abstract}
This article intends to examine the phenomenon of pornography among the young generation, and its implications for the literature study approach. Data analysis showed that based on the results of research in one region of Indonesia, found $68.70 \%$ of the young generation claimed to have had sexual relations. As many as $93,00 \%$ claimed to have seen porn sites, and as many as $12,20 \%$ claimed to have had an abortion. Regarding the phenomenon of pornography among the young generation, there are at least three contributing factors, including: (1) the usage of internet networking sites freely; (2) poor understanding of adolescents about reproductive organs; and (3) low sexual education, both within the family and school. To prevent young generation from falling into pornography, there are a number of steps that are offered including: (1) should be actively involved in various positive activities; (2) should be active and creative in doing something in the interests of the nation and state; (3) should understand the various negative impacts that can be caused by having free sex; and (4) should be actively involved in the village development program, starting from the planning, implementation, and evaluation stages.
\end{abstract}

Keywords: pornography, young generation, information technology.

\section{INTRODUCTION}

\subsection{Background}

In the future, the nation is in the hands

of the young generation, therefore parents, the community and the government has no choice but to give them enough attention and affection. Related to this matter, sociologists said, 'the load of certain values is always charged to young people, so that idealism and vital life force are attached to the term youth and young generation (Suharja in Suda, 2008: $1)$.

But in reality, many parents do not understand the condition, so they are more concerned with family economic affairs than paying attention to the development of their children. As a result, many young people are disappointed, even frustrated because of the lack of attention from parents, or the environment towards their existence. Thus they also try to find their existence outside the home and away from the supervision of parents. As a result, many young people are mistaken and many of them fall into criminal acts. For example, drunk drinking, gambling, speeding on the road, and lapsed into immoral acts, namely pornography. Like the case allegedly 
experienced by a student of a favorite college in Jakarta, (Panjimas.com, 14 November 2017). She did intimate relationship with a man who is not her husband and was shared to social media. She claimed to have deliberately recorded the act of pornography, with the intention of making personal documents.

However, unlucky video fell into the hands of irresponsible people and disseminated to social media, eventually becoming a trending topic of social media (Swarniti, 2020). Such matter has the potential to be reported to the authorities on charges of violating article 29 of Law No.44 of 2008 concerning Pornography. The article reads "every person who manufactures, makes, reproduces, multiplies, distributes, broadcasts, imports, exports, offers, sells, rents, or provides pornography as referred to in Article 4 paragraph (1) shall be liable to a imprisonment minimum of 6 (six) months and a maximum of 12 (twelve) years and/or criminal fines of at least Rp 250,000,000.00 (two hundred and fifty million rupiah) and a maximum of Rp 6,000,000,000.00 (six billion rupiah).

The second case, is the circulation of pornographic content through one social media application, which is Whats App, the culprit is also suspected to be teenagers (Swarniti, 2021). This can damage the moral attitude of the young generation who watched the video.
Imagine if 35 million Whats App users in Indonesia accessed the content, how many human brains were filled with pornography. Beginning from the two examples of cases above, it can be understood that pornography not only damages the moral attitudes of the perpetrators, but also damages the moral attitudes of those who view or access the content. In today's digital technology, any information can be accessed with just a touch of a finger. With the capital of the gadget/android, people can already explore any part of the virtual world without any control from any party, even pornographic content can easily be obtained (Swarniti, 2021). In this regard, it is interesting to study how to deter, protect, or perhaps protect young generation from such actions, so that they are free from crime, especially in the context of pornography.

\subsection{Research Method}

This article was written using the library method, namely by reducing various records of past events whose data were obtained from various library data. For example, in the context of collecting data for analytical purposes, researchers collect a number of papers, especially monumental works from someone or some people who are related to the theme under study. Furthermore, 
the data or facts contained in these literature books are analyzed according to the purpose of writing this article.

The techniques of data collecting are carried out with document study techniques, namely by collecting data and information from various reference books, documents, such as laws, clippings, and various related articles, which appear in the mass media (Santika, 2020). To fulfill the criteria of the degree of trust, several data checking methods are used, such as perseverance of observation, triangulation, and adequacy of references used (Moleong, 1991: 175). The data collected was analyzed by using a qualitative descriptive approach, namely by summarizing, selecting the main points, then focusing on the important matters, then looking for themes or patterns, making it easier to provide code to certain aspects. Data analysis of this model is carried out continuously and then systematically presented, then processed, interpreted, and interpreted according to the theoretical framework used as the basis for thinking.

\section{FINDING AND DISCUSSION}

\subsection{Pornography Phenomenon among Young Generation}

Pornography according to article 1 (1) of Law No. 44 of 2008 is pictures, sketches, illustrations, photographs, writing, sounds, sounds, moving pictures, animations, cartoons, conversations, gestures, or other forms of messages through various forms of communication media and/or public display, which contains obscenity or sexual exploitation that violates the norms of decency in society. In articles 4-12 of Law No. 44/2008 the definition of pornography includes sexual intercourse, sexual violence, masturbation, nudity, or an impressive display of nudity. Article 6 regulates "the prohibition of everyone listening, watching, utilizing, having or saving pornographic products and is given an explanation therein" that the prohibition of saving or having is not included for themselves and their own interests.

If seen at a glance the description of the Act above seems to emphasize that if someone commits an act of pornography for themselves is allowed and not touched by the Act. It is thus impressed that the responsibility to control the behavior and moral attitudes of the young generation is only the responsibility of parents and themselves. Even though when referring to $\mathrm{Ki}$ Hajar Dewantara (in Suda, 2017: 7) the responsibility of the souls of children lies in three institutions, namely family, school, and community. But in reality, parents were too busy with family economic matters (read: Bring Atmdja, 2010: 112), so that children today are free to do activities 
outside the home, without parental control. They are free to take any action, such as drinking, playing gambling, including accessing porn sites.

According to the Minister of Women's Empowerment and Child Protection, Yohana Susana Yembise, no less than 25,000 Indonesian teenagers access pornographic sites every day. She knew the number from a Thai guest in charge of cyber crime, but was not named. The number is an image which is known through satellite monitoring. Furthermore according to Yohana, accessing porn sites can be monitored through the communication media security system, unless the pornography is copied to a compact disk or cassette, it may not be monitored, but those through the hand phone or cell phone are clearly visible. Yohana also asked for the results of a special observation in Jakarta, and she was surprised to find out the results, because according to her, there was no empty spot for accessing pornographic sites in Jakarta, so it was called a pornographic emergency area (Tempo.co, 5 July 2019).

According to the Chairperson of the National Commission (Komnas) for Child Protection, Arist Merdeka Sirait (in Republika.co.id, July 27, 2012) that of 423 junior and senior high school teenagers studied in mid-2011, in the Toba Samosir (Tobasa) jurisdiction, it turns out as many as $68,70 \%$ claimed to have had sexual relations with peers, girlfriends, and adult masher, as many as 93, $00 \%$ claimed to have watched pornographic shows, and $12,20 \%$ claimed to have had an abortion. If depicted in the form of a curve, then it looks like the picture below.

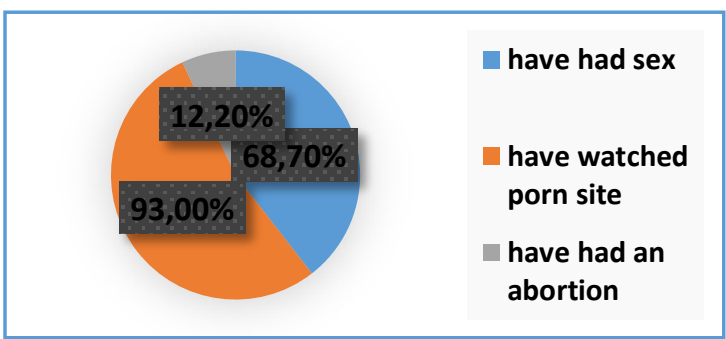

Quoted from (Republika.co.id, $27^{\text {th }}$ of July 2012)

Likewise, a study conducted by two lecturers of the Faculty of Psychology of the University of August 17, 1945 Samarinda (2018), showed that many people ignored the effects of pornography, even though the negative effects were greater than the negative effects of drug addicts in terms of damaging the brain. According to the pornography 
addiction expert from the USA, Mark B. Kastlemaan, delivered in the 'Executive Seminar on the Control of Pornography Addiction, in Jakarta', (9/27/2010), that pornography addicts can cause damage to 5 (five) parts of the brain, especially in Pre Frontal Cortek (the part of the brain that is just behind the forehead). While drug addicts can cause damage to three parts of the brain. Damage to this part of the brain makes people unable to plan, unable to control their passions and emotions, and unable to make decisions and various executive roles of the brain as controlling impulses (Santika et al., 2021). Furthermore, according to Mark in pornography addicts, the brain will stimulate the production of dopamine and endorphins, which are brain chemicals that make you feel good and feel better. In normal conditions, these substances will be very beneficial to make people healthy and live a better life. However, with pornography the brain will experience hyper stimulation (excessive stimulation), so the brain will work with extreme then shrink and eventually damaged.

\subsection{The Factors That Cause Young Generation to be involved in Pornography and its Implications}

Factors causing the fall of young generation in the act of pornography in general can be categorized into two factors, namely internal factors and external factors. Internal factors are factors that originate from within the child itself, while external factors are factors that originate from outside the child. Internal factors in this case are intended for someone to do pornography, because it is a desire that arises from within their selves. For example, children do pornography not because of a friend's invitation, and not because of environmental influences, but because there is an intention that comes from within themselves. While the external influence means that such acts are carried out by teenagers because of the influence of friends or the surrounding environment. For example, at first someone did not have the intention to commit pornography, but because the influence of friends or the surrounding environment was so strong, they finally did it. This is in line with the view of adherents of the convergence flow which says that: children's mental development is determined by two factors that support each other, namely innate and environmental factors. Both can not be separated (interdependence) (Ahmadi, 1991: $21)$. Beginning from this view can be built an understanding that the personality of a child is determined by two factors that support each other, namely the talent factor and the environment. 
According to Sandika (2011: 11) in adolescents, the sense of wanting to try something is very dominant influencing their behavior, so it is not uncommon to harm themselves. For example, when they hang out with children who used to have free sex, then at least they will also be affected to try to have free sex. Likewise, if the association is alcoholics, at least they will also be affected to try to consume liquor, and so on.

This is actually an autorefection of the existence of today's young generation, which is manifested in the form of a hedonic lifestyle. They tend to like to pursue the pleasures of life for a moment, which in this context is called 'the' fake paradise of modern society'. They think, if with a pattern of life like that will get peace or happiness, even though all of that is pseudo happiness and real happiness is 'moksartham jagadhita ya ca iti dharma'. But in order to achieve this, spiritual discipline is needed, which in the Hindu context is called 'spiritual sadhana'. According to the Hindu view, humans can only achieve real and lasting peace through spiritual discipline. Or in the other hand that peace, can only be achieved by someone who has purified his mind. While people who have envy, jealousy, greed, and their minds are filled with lust, it is very difficult to find real peace/happiness.

\subsection{The Ways to Prevent Young Generation from Doing Pornography}

Has been mentioned in the previous description, that the younger generation is the next generation of the nation. Therefore there is no reason for anyone not to pay special attention to them, because it is in their hands that the fate of this nation will be inherited. However, in reality there are still many young generations of this nation who have not had clear goals in life. As a result, it is not uncommon among those who fall into criminal acts, such as becoming abused, taking illegal drugs, drinking alcohol, speeding on the street, and committing pornography. Especially in the current era of digital technology, people, especially the young generation, can easily access any information through their cellphones, including easily accessing content that contains pornographic acts.

In this context, Piliang (2005: 116117) emphasizes the circulation of commodities which explores almost all corners of life, has resulted in the circulation of sexual circulation, and the indulgence in lust goes to explore almost every corner of space. Thus according to him disappeared dimensions of secret, fantasy, and moral. This means that at this time there is no secret behind a body without a wrapper in computer bits, there is no moral dimension in transparent films, and so 
on. Seeing and realizing the digital world like that, makes the community, especially the young generation must be able to understand the current situation and conditions, and at the same time think of various efforts that can be taken to prevent themselves from falling into various deviant actions. Related to this there are several ways that can be done to prevent young generation from engaging in various deviant behaviors, including: (1) should be actively involved in various positive activities, so that there is not much time to do things that are contrary to values religious values and legal norms in society; (2) should be active and creative in doing something in the interests of the nation and state; (3) should understand the various negative effects that can be caused by free sex; and (4) should be actively involved in the village development program, starting from the planning, implementation, and evaluation stages.

\section{CONCLUSIONS SUGGESTION}

AND

\subsection{Conclusions}

Based on the description above, it can be concluded: (1) The phenomenon of pornography among young generation in Indonesia is classified as being alarming. Because based on the results of research in one region in Indonesia, it was found
$68.70 \%$ of the younger generation claimed to have had sexual relations; As many as $93.00 \%$ claimed to have seen porn sites, and as many as $12.20 \%$ claimed to have had an abortion; (2) There are three basic factors as a factor causing young generation to commit pornography: (a) unhealthy use of internet networking sites; (b) poor understanding of adolescents about reproductive organs; and (c) low sexual education, both in the family and school environment; (3) Several ways to prevent young generation from engaging in pornographic behavior: (a) actively involved in various positive activities; (b) actively and creatively doing something for the benefit of the nation and state; (c) understand the various negative effects that can be caused by free sex; and (d) are actively involved in the village development program, starting from the planning, implementation, and evaluation stages

\subsection{Suggestion}

Based on the conclusions above, several suggestions can be made including:

(1) It is suggested to the young generation to demand a lot of knowledge, so that later in life they can more easily live this life; (2) It is advisable for parents 
to help young generation find their identity, so they can avoid various criminal acts, especially pornography; (3) The government, both central and regional, should always provide opportunities for young generation to be involved, both directly and indirectly in development programs.

\section{BIBLIOGRAPHY}

Ahmadi, Abu, 1991. Psikologi Perkembangan. Jakarta: Rineka Cipta.

Atmadja, Nengah Bawa, 2010. Ajeg Bali, Gerakan Identitas Kultural, dan Globalisasi. Yogyakarta: LKiS.

Diana Imawati (1) dan Meyritha Trifina Sari 2018. Studi Kasus Kecanduan Pornografi Pada Remaja. Journal article Motiva • 2018 DOI 10.31293/mv.v1i2.3688.

Moleong, Lexy J.,1991. Metodologi Peneltian Kualitatif. Bandung: PT Remaja Rosdakarya.

Panjimas.com, $14 \quad$ November 2017. Membincang Pornografi dan Pornoaksi, Surga Palsu Masyarakat Kapitalis.

Piliang, Yasraf, Amir, 2005. Dunia yang Dilipat Tamasya Melampaui Batas-Batas Kebudayaan. Yogyakarta: Jalasutra.

Republika.co.id, 12 Juli 2012. Inilah Pemicu Remaja Lakukan Seks Bebas

Sandika, Ketut, 2011. Pendidikan Menurut Veda. Denpasar:Pustaka Bali Post.

Santika, I. G. N. (2020). Optimalisasi Peran Keluarga Dalam Menghadapi Persoalan Covid- 19 : Sebuah Kajian Literatur. Jurnal Ilmiah Ilmu Sosial, 6(2), 127-137. https://doi.org/http://dx.doi.org/10.23887/ jiis.v6i2.28437

Santika, I. G. N., Kartika, I. M., Ayu, I. G., \& Darwati, M. (2021). Reviewing The Handling Of Covid-19 In Indonesia In The Perspective Of The Pancasila Element Theory ( TEP ). Jurnal Etika Demokrasi (JED), 6(2), 40-51. https://doi.org/https://doi.org/10.26618/je d.v6i2.5272

Santika, I. G. N., Kartika, I. M., \& Rini Wahyuni, N. W. (2019). Pendidikan Karakter: Stusi Kasus Peranan Keluarga terhadap Pembentukan Karakter Anak Ibu Sunah di Tanjung Benoa. Jurnal Kajian Pendidikan Widya Accarya FKIP Universitas Dwijendra, 10(1).

Santika, I. G. N. (2017). Strategi

Meningkatkan Kualitas SDM Masyarakat

Desa Padangsambian Kaja Melalui

Pendidikan Karakter Berbasiskan

Kepedulian Lingkungan Untuk

Membebaskannya Dari Bencana Banjir.

Widya Accarya. 9 (2)

Santika, I. G. N. (2020). Optimalisasi Peran

Keluarga Dalam Menghadapi Persoalan

Covid-19: Sebuah Kajian Literatur.

Jurnal Ilmiah Ilmu Sosial. 6 (2), 127-137.

Suda, I Ketut, 2017. 'Merajut Pendidikan

Bercitarasa Sloka'. (Dalam Majalah Wartam Edisi 27/th.3/Mei 2017 hal 6-7. 2008. Anak dalam Pergulatan Industri Kecil dan Rumah Tangga di Bali. Yogyakarta: Aksara Indonesia. , 2004. 'Faktor Penyebab Munculnya Fenomena Pelacuran Anak-Anak (Suatu Tinjauan Sosiologis)". Dalam Media Komunikasi FPIPS, Fakultas Pendidikan Ilmu Pengetahuan Sosial, Institut Keguruan dan Ilmu Pendidikan Negeri Singaraja, Vol.3, No.2 Agustus 2004. Halaman 91-101.

Suharja, Arya, 1992. 'Generasi Muda Hindu: Kelana atau Tawaran Sejarah'. 
Dalam Putu setia (ed.) Cendekiawan Hindu Bicara. Denpasar: Yayasan Dharma Naradha.

Starinne Rosy Adria, 1998. 'Pelacuran Anak: Sebuah Studi Kasus di Kuta, Bali". (Dalam Majalah Filia, No.6 tahun I/Desember 1998, 3 15.

Swarniti, N. W. (2020). Fenomena Morfologi pada Berita-Berita di CNN Indonesia Mengenai Covid-19: Kajian Linguistik. In COVID-19 Perspektif Susastra dan Filsafat (p. 93). Yayasan Kita Menulis.

Swarniti, N. W. (2021). A Corpus Based Approach to the Analysis of
Structures in Prepositional Phrase.

Yavana Bhasha: Journal of English Language Education, 4(1), $18-22$.

https://doi.org/http://dx.doi.org/10 $.25078 / \mathrm{yb} . v 4 \mathrm{i} 1.2207$

Swarniti, N. W. (2021). The Analysis of Semantics Meaning Found In Comments of Instagram Account of Info Denpasar. Prosiding Seminar Nasional Linguistik Dan Sastra (SEMNALISA), 193-199.

Tempo.co, 5 Juli 2019. Menteri Yohana: 25 Ribu Remaja Akses Pornografi Tiap Hari 